Portland State University

PDXScholar

3-22-2019

\title{
Maximizing Community Resiliency Through LINC
}

Ariel R. Bushnell

Portland State University

Follow this and additional works at: https://pdxscholar.library.pdx.edu/honorstheses

Let us know how access to this document benefits you.

Recommended Citation

Bushnell, Ariel R., "Maximizing Community Resiliency Through LINC" (2019). University Honors Theses.

Paper 689.

https://doi.org/10.15760/honors.707

This Thesis is brought to you for free and open access. It has been accepted for inclusion in University Honors Theses by an authorized administrator of PDXScholar. Please contact us if we can make this document more accessible: pdxscholar@pdx.edu. 


\section{Portland State University}

PDXScholar

\section{Maximizing Community Resiliency Through LINC}

Ariel R. Bushnell

\section{Let us know how access to this document benefits you.}

Follow this and additional works at: https://pdxscholar.library.pdx.edu/honorstheses

This Thesis is brought to you for free and open access. It has been accepted for inclusion in University Honors Theses by an authorized administrator of PDXScholar. For more information, please contact pdxscholar@pdx.edu. 
Maximizing Community Resiliency Through LINC

by

Ariel R. Bushnell

An undergraduate thesis submitted in partial fulfillment of the requirements for the degree in

Bachelor of Arts

in

University Honors

and

International Development \& Conflict Resolution

Thesis Adviser:

Amanda Smith Byron

Portland State University

2019 


\section{Table of Contents:}

Abstract.............................................................. 3

Introduction................................................... 3-4

Literature review.............................................. 4-5

Methodology $\ldots \ldots \ldots \ldots \ldots \ldots \ldots \ldots \ldots \ldots \ldots \ldots \ldots \ldots \ldots \ldots \ldots \ldots \ldots \ldots, 5-6$

Definitions and values sorting.................................. 6-7

Disaster types observed....................................... 7

Data Analysis..................................................... 8

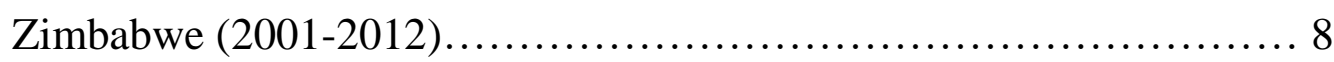

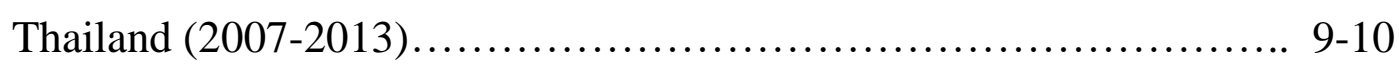

Compiled Results............................................. 10

Discussion..................................................... 10

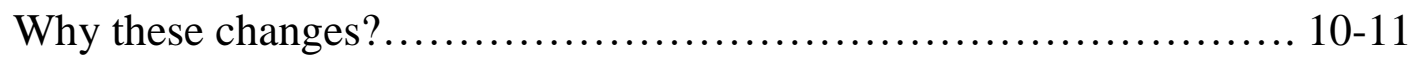

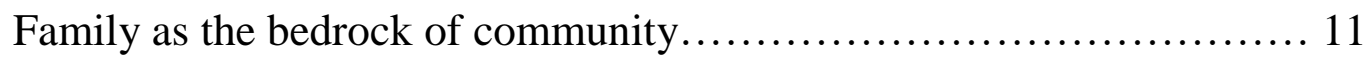

Conclusion.................................................... 11

References..................................................... 12 


\begin{abstract}
:
When humanitarian or natural disasters devastate an area, the surrounding communities become an integral factor in the probability of recovery for that area and are powerful stakeholders in shaping the quality of practice to heal and rebuild. The first response that civilians receive after weathering communal trauma is through the personal networks and community connections that citizens have built their lives within. In the wake of natural or humanitarian disasters, community values are affected by the recovery processes taking place. Understanding patterns of change within the values of communities that have experienced disaster uncovers the importance of incorporating psychological, biological, social, and spiritual development when engaging in community development. Understanding the importance of these values and digesting them into the practice of community development and disaster response facilitates the building of resilient communities that flourish together and are empowered to rebuild and heal by way of their own connections and internal resources.
\end{abstract}




\section{Introduction:}

Walsh (2007) recognizes the importance of community networks as "essential resources in trauma recovery when their strengths and potential are mobilized" (p. 107). When these connections are not utilized or considered in developing strategy, community trauma can escalate with unsafe and rippling effects. Community resilience is built by the social interactions that occur in our daily lives, and is key to the development of a society. Community resilience acts as a security net of support when individual or community trauma is experienced. When members of a community exercise their resiliency and "come together around practical concerns, they enhance their social connectedness" (Saul \& Landau, 2004, p. 295). Resiliency fosters the sharing of community information and the resources necessary to recover from trauma. When members of a community experience hardship, their internal networks of connection act as a first response to the longer term processes of recovery. Increased community connection widens the pool of resources present and available for use in first response and longer-term recovery processes. A simple example is offered to illustrate this: If I am in dire need of a cup of sugar while my neighbor has a surplus of it, it is our internal connection that is utilized for my accumulation of resource, which is occurring within a mutual exchange. My built connection with my neighbors informs me of who to ask, how to find them, and how to acquire my needed resource without having to leave my street.

External aid resources brought in post-disaster are most effective when they can map interventions by plugging into the resiliency already cultivated within the community (Saul \& Landau, 2004). Community members have the most expertise in the recovery of their area: local knowledge of social divides, knowledge of vulnerable demographics, networks of long-term relationships cultivated over time, solidarity, etc. Recovery programs that utilize the local 
knowledge of the community render success because community members are undoubtedly the most invested in their own recovery. Forms of external aid and international intervention and are commonly used as resource solutions for regions experiencing disaster within the field of international development. This type of intervention does not harness the communal connections made pre-disaster and do not work to foster community-linking systems that build resiliency and sustain recovery. Without the local values of the community present within the recovery processes unfolding, much damage can be done and systems unraveled that were once waging internal community connection.

\section{Literature Review:}

The Linking Community Systems Resiliency Model (LINC) has been used globally over the past three decades to guide communities into accessing their naturally occurring resources for the creation and execution of disaster recovery programs that focus on rebuilding infrastructure and encouraging/supporting healing from experienced trauma. These naturally occurring resources exist in a vast range but are defined as being the services, tools, and characteristics within a community that affect the quality of life for present and future generations. This method is used in response to both humanitarian and natural disasters and has facilitated intervention programs for single-event traumas, weather devastation and humanitarian crises of systemic violence and ethnic cleansing. LINC has been implemented in disaster recovery zones such as Kosovo, New York City, Rwanda, Northern Ireland, Serbia, Australia, and Nigeria since its development in 1997 (Landau \&Mackenzie-Weaver, 2006). LINC utilizes naturally occurring resources that communities possess into four interconnected components: biological, psychologi- 
cal, social and spiritual. These domains are recognized as containing assets (information, equipment, protection, sustenance) that should be harnessed and utilized for intervention and recovery for communities in the wake of disaster (Landau, 2007).

LINC operates with the knowledge that these components are inherent in every community and capture the values, identities and methods of meaning-making within a community (Saul \& Landau, 2004). They are also domains of connection that can hold access to "time, material, knowledge, skill, money, space for assembly and activities," and other tangible assets for recovery (Landau, 2007). The LINC model aims to facilitate communities in regaining self-sufficiency, without the messy entanglement of international aid corporations and an onslaught of unsure resources, while tapping into known community links that reflect the values and goals of the population recovering. For example, after the tsunami hit Thailand in 2004, the nation was flooded with a surplus of rice from foreign aid corporations that were unaware of the economic importance of Thailand's rice production. The flood of a cheaper surplus devastated the agricultural and processing sectors of Thailand's rice production market, plummeting Thailand's GDP by 7\% and putting millions of Thailand's farmers out of business from 2004-2007 (Rigg, et. al, 2008). When foreign aid is not in congruence with the needs of the region, dire consequences can further hinder the recovery process.

Since the four components identified in the LINC model are inherent in every community, this study seeks to pinpoint which human values are most important to scaffold in development and community building sectors as tactics for single-event, natural, or humanitarian disaster prevention and recovery (Saul \& Landau, 2004). By comparing the human values of communities before and after experienced disaster with the four components of the LINC model, the val- 
ues and changes in values of a community can be observed and analyzed. Analysis of these comparisons investigates the importance of integrating development decisions and policymaking with interior human values, which is encouraged by the LINC linking community systems model, and is necessary for building resilient communities and facilitating long-term disaster recovery (Landau \& Weaver, 2006).

\section{Methods and Data Collection:}

In order to find access to a wide variety of crisis event survivors, the www.worldvaluessurvey.org data base was used to analyze the patterns and changes within the human values in areas of experienced disaster by comparing pre-disaster and post-disaster values rankings. The WVS invites respondents to rank common values by rate of importance within their lives, and also provides country specific information allowing researchers to observe and evaluate trends within countries, and any changes over time. This survey is conducted by a global network of social scientists united under the World Values Association. These values surveys have been conducted in over 20 different languages and in 100 different countries since 1981. WVS seeks to inform policy makers and scientists about the beliefs, motivations, and values of citizens throughout the globe. This study utilizes 20 values identified by WVS in two separate regions of experienced disaster recovery. The four components of the LINC model (biolog-

ical, psychological, social, spiritual) will be used as categories to help code the human values, sorting them into these four domains to be observed. 


\section{Table A: WVS Values and LINC correlating LINC components}

\begin{tabular}{|c|c|c|}
\hline & A & B \\
\hline 1 & WVS Survey Values: & Related LINC components: \\
\hline 2 & Family & social/biological \\
\hline 3 & Friends & social \\
\hline 4 & Politics & social \\
\hline 5 & Work & biological \\
\hline 6 & Religion & spiritual \\
\hline 7 & Independence & psychological \\
\hline 8 & Responsibily & psychological \\
\hline 9 & Imagination & spiritual \\
\hline 10 & Tolerance & psychological \\
\hline 11 & Obedience & psychological \\
\hline 12 & Economic Growth & biological \\
\hline 13 & Adventure \& Risk & biological/psychological \\
\hline 14 & Care for Nature & biological/psychological \\
\hline 15 & Tradition & social/spiritual \\
\hline 16 & Technology & biological \\
\hline 17 & Income Equality & social \\
\hline 18 & Competition & biological \\
\hline 19 & Fate & spiritual \\
\hline 20 & Solving/Aiding Poverty & social \\
\hline 21 & Education & psychological \\
\hline
\end{tabular}

Merriam-Webster Dictionary definitions were used to define both the WVS values and LINC model domains in order to match them accordingly. WVS values with two LINC model domains listed are represented as being part of both component categories. Since this is a qualitative study, the process of defining and sorting this data set was based on interpreting corresponding meanings from dictionary definitions (Table A). WVS codebooks for each country for 
each year were combed through to extract 20 diverse world values questions that were similar in grammar and format, and were present in all four data set years observed. Zimbabwe data (20012012) was chosen as a case study because of the country's experience with recovering from a period of structural violence and ethnic cleansing during the dates listed above. The case study of Zimbabwe looks at changes in world values during the pre-disaster and post-recovery periods in a region affected by humanitarian disaster. Data from Thailand (2007-2013) was chosen as a case study because of the country's experience recovering from a tsunami during the dates listed above. The case study of Thailand offers insight into changes in world values during the postdisaster and post-recovery periods in a region affected by natural disaster. Note that the WVS values uses a numeric designation (v\#\#\#), which is listed in the data graphs of the analysis section, so as to reference where each value is located in the WVS codebooks of each country and year. This numeric reference is important for reproducing this study because the WVS questions are not always in the same order from year to year. There is also a N/A cell listed in the Zimbabwe data set because one of the WVS values questions is missing from the survey conducted in 2001 and therefore, it cannot be measured for comparison in this study (see Table B below). 
Analysis:

Table B: Zimbabwe Values Data (2001-2012)

\begin{tabular}{|c|c|c|c|c|c|c|}
\hline & A & B & C & D & $E$ & $\mathrm{~F}$ \\
\hline 1 & Values & Zimbabwe 2001 & Zimbabwe 2012 & Difference Calculated & Coding \# (2001) & Coding \# (2012) \\
\hline 2 & Family & 97.3 & 97.3 & 0 & $\mathrm{v} 4$ & v4 \\
\hline 3 & Friends & 34.9 & 37.8 & $2.9(+)$ & v5 & v5 \\
\hline 4 & Politics & 14.1 & 20.7 & $6.6(+)$ & v7 & v7 \\
\hline 5 & Work & 90 & 85.4 & $4.6(-)$ & v8 & v8 \\
\hline 6 & Religon & 77.6 & 83.5 & $5.9(+)$ & v9 & v9 \\
\hline 7 & Independence & 26.2 & 39.1 & $12.9(+)$ & v15 & v15 \\
\hline 8 & Responsibily & 17.6 & 43.1 & $4.5(+)$ & v17 & v17 \\
\hline 9 & Imagination & 11.1 & 13.3 & $2.2(+)$ & $\mathrm{v} 18$ & v18 \\
\hline 10 & Tolerance & 78.2 & 63.8 & $14.4(-)$ & $\mathrm{v} 19$ & $\mathrm{v} 16$ \\
\hline 11 & Obedience & 68.1 & 70.1 & $2(+)$ & v24 & v21 \\
\hline 12 & Economic Growth & 61.7 & 72.4 & $10.7(+)$ & v36 & v60 \\
\hline 13 & Adventure \& Risk & N/A & 16.3 & N/A & N/A & v76 \\
\hline 14 & Care for Nature & 58.3 & 23.9 & $34.4(-)$ & v37 & v78 \\
\hline 15 & Tradition & 35.8 & 26.1 & $9.7(-)$ & v185 & v79 \\
\hline 16 & Technology & 76.5 & 22.3 & $54.2(-)$ & v129 & v192 \\
\hline 17 & Income Equality & 14.8 & 4.2 & $10.6(-)$ & v141 & v96 \\
\hline 18 & Competition & 61.7 & 30 & $31.7(-)$ & v144 & v99 \\
\hline 19 & Fate & 14.4 & 5 & $9.4(-)$ & v82 & v55 \\
\hline 20 & Solving/Aiding Poverty & 21.3 & 57.4 & $36.1(+)$ & v145D & v80 \\
\hline 21 & Education & 33 & 50.6 & $17.6(+)$ & v226CS & v248 \\
\hline \multicolumn{7}{|c|}{22} \\
\hline 23 & Orange $=\mathrm{MAX}$ increase & & & & & \\
\hline 24 & Pink= MAX decrease & & & & & \\
\hline 25 & Green $=$ MIN increase & & & & & \\
\hline 26 & Blue $=$ MIN decrease & & & & & \\
\hline 27 & Yellow $=$ N/A, missing data & & & & & \\
\hline
\end{tabular}

\section{Zimbabwe 2001-2012:}

MAX Increase: Psychological values MIN Increase: Psychological values MAX Decrease: Biological values MIN Decrease: Spiritual values
- For Zimbabwe (2001-2012):

the values that changed the most over time in correlation to the LINC components are: Psychological and biological 


\begin{tabular}{|c|c|c|c|c|c|c|}
\hline & A & B & $\mathrm{C}$ & D & E & $\mathrm{F}$ \\
\hline 1 & Values & Thailand 2007 & Thailand 2013 & Difference Calculated & Coding \# (2007) & Coding \# (2013) \\
\hline 2 & Family & 86 & 88.6 & $2.6(+)$ & $\mathrm{v} 4$ & $\mathrm{v} 4$ \\
\hline 3 & Friends & 33.1 & 32.3 & $0.8(-)$ & v5 & v5 \\
\hline 4 & Politics & 31 & 32 & $1(+)$ & v7 & v7 \\
\hline 5 & Work & 57 & 66.6 & $9.6(+)$ & v8 & v8 \\
\hline 6 & Religon & 56 & 56.6 & $0.6(+)$ & v9 & v9 \\
\hline 7 & Independence & 48.2 & 35.9 & $12.3(-)$ & $\mathrm{v} 12$ & $\mathrm{v} 12$ \\
\hline 8 & Responsibily & 60.6 & 65.7 & $5.1(+)$ & $\mathrm{v} 14$ & v14 \\
\hline 9 & Imagination & 28.5 & 23.3 & $5.2(-)$ & v15 & v15 \\
\hline 10 & Tolerance & 58 & 64.7 & $6.7(+)$ & v16 & v16 \\
\hline 11 & Obedience & 53.8 & 44.2 & $9.6(-)$ & v21 & v21 \\
\hline 12 & Economic Growth & 66.3 & 47.5 & $18.8(-)$ & v69 & v76 \\
\hline 13 & Adventure \& Risk & 3.4 & 8.2 & $4.8(+)$ & v86 & v77 \\
\hline 14 & Care for Nature & 7 & 21.9 & $14.9(+)$ & v88 & v78 \\
\hline 15 & Tradition & 13.8 & 29.3 & $15.5(+)$ & v89 & v79 \\
\hline 16 & Technology & 10.7 & 21.9 & $11.2(+)$ & v91 & v91 \\
\hline 17 & Income Equality & 3.1 & 18.4 & $15.3(+)$ & v116 & v96 \\
\hline 18 & Competition & 10.9 & 14.2 & $3.3(+)$ & v119 & v99 \\
\hline 19 & Fate & 4 & 4.6 & $0.6(+)$ & v122 & v100 \\
\hline 20 & Solving/Aiding Poverty & 63.7 & 46.8 & $16.9(-)$ & v168 & v180 \\
\hline 21 & Education & 61.9 & 60.7 & $1.2(-)$ & v172 & v182 \\
\hline \multicolumn{7}{|l|}{22} \\
\hline 23 & Orange $=\mathrm{MAX}$ increase & & & & & \\
\hline 24 & Pink= MAX decrease & & & & & \\
\hline 25 & Green $=$ MIN increase & & & & & \\
\hline 26 & Blue $=$ MIN decrease & & & & & \\
\hline 27 & Yellow $=$ N/A, missing data & & & & & \\
\hline
\end{tabular}

Table C: Thailand Values Data (2007-2013)

Thailand 2007-2013:

MAX Increase: Social values

MIN Increase: Spiritual values

- For Thailand (2007-2013):

MAX Decrease: Biological, social, and

psychological values (three-way tie)

MIN Decrease: Social, psychological, the values that changed the most and spiritual values (three-way tie) over time in correlation to the LINC components are: Social and spiritual values.

\section{Compiled Results:}


Zimbabwe's biggest changes occurring in psychological and biological values show that changes in mental/emotional values and changes in value affecting life and living organisms are present in communities affected by humanitarian disaster. Thailand's biggest changes occurring in social and spiritual values show that changes in alliance/confederate values and changes affecting the values around spirit and the vital principles of life are present in communities affected by natural disaster. It is not surprising that changes in values differ when the types of disasters that took place in both of these regions differ in nature and recovery needs. What is significant by the comparison of Zimbabwe and Thailand world value changes is that all four of the LINC components are reflected equally in the biggest changes in values when we combine the data for both countries: Zimbabwe 2001-2012 (psychological, biological), Thailand 2007-2013 (social, spiritual).

This particular insight from the data comparison starkly echoes the LINC model's philosophy concerning the importance of equally incorporating these four components to achieve a holistic framework for disaster recovery and community resilience practice. By designing processes that intentionally develop these four components equally within a community, practitioners and citizens can feel confident that actions toward recovery and resilience will happen collaboratively, with primary attention to the values and capabilities of the community. Linking systems that exist within the population will be utilized, encouraging community connection that contributes to the creation of more linking systems. This process is how resiliency is built (Walsch, 2007). When development practices operate with theory that is conscientious of this process, formulated systems can support communities in thriving harmoniously and consequentially with communal resilience, aiding the ability to recover more quickly from experienced trauma.

\section{Discussion:}


Zimbabwe's data reflects an increase in values concerning the solving of aid/poverty, as well as increased value of education and independence (see Table B). Countering that, Zimbabwe decreased in values concerning technology, care for nature, and competition. Since Zimbabwe withstood political unrest, government-backed ethnic cleansing, and the demolition of homes in impoverished communities, it can be speculated that post-recovery Zimbabwe shifted to value humanitarian needs, higher education, and internal independence after experiencing humanitarian disaster.

Thailand's data reflects an increase in values concerning tradition, care for nature, and income equality (see Table C). Thailand also decreased their values concerning economic growth, solving poverty, and independence. After experiencing a deadly tsunami and the economic devastation that took place, it can be speculated that post-recovery Thailand shifted to value tradition, connection to nature, and income equality. Thailand's shifted value of tradition and connection to nature point toward a renewed importance in making sense of the innate and spontaneous characteristics of naturally-occurring disaster. The shifted value of income equality illustrates the nation's desire to maximize economic growth for all for the sake of maximizing recovery after experiencing disaster. It could also be occurring in connection to the flooding of external aid that Thailand experienced from foreign sources, which saturated many industries, threatening the economic livelihood of one portion of the population while supplying quick relief to the other.

"Family," listed as the first world value for both countries reflects as unchanged or nominally changed in both cases. Family is also the highest ranked value of both countries, exceeding the other world value measurements by upwards of $25 \%$ (see Table B and C). The LINC model 
renders family as the "bedrock" of community and arguably the bedrock of life, which is represented in the data compiled by this study (Landau, 2007).

\section{Conclusion:}

Community is an integral factor in the probability of recovery for an area rallying to heal from disaster (Saul \& Landau, 2004). Community links are powerful stakeholders in shaping the quality of practice to heal and rebuild after experienced turmoil. As the values in a community morph and change during the course of disaster recovery, the combined findings of this study reflect the LINC model's four linking community components (psychological, social, biological, spiritual) as domains of equal importance in the curation of community resiliency. By incorporating the awareness of these components into disaster recovery theory, conscientious use of the internal resources of a community can be harnessed to further build resiliency and facilitate healing in an equitable and supportable way. Development and community building theory can also use the power of community resilience and the awareness of Landau's four LINC components as pillars of support for the curation of policy that opts to stimulate linking community systems and build collaborative connection for unified change.

\section{Resources:}

Landau, J., \& Weaver, A. M. (2006). The LINC Model of Family and Community Resilience: New approaches to disaster response. Journal of Family and Consumer Sciences, 98(2), 11.

Landau, J. (2007). Enhancing resilience: Families and communities as agents for change. Family process, 46(3), 351-365. 
Plough, A., Fielding, J. E., Chandra, A., Williams, M., Eisenman, D., Wells, K. B., ... \& Magaña, A. (2013). Building community disaster resilience: perspectives from a large urban county department of public health. American Journal of Public Health, 103(7), 1190-1197.

Rigg, J., Grundy-Warr, C., Law, L., \& Tan-Mullins, M. (2008). Grounding a natural disaster: Thailand and the 2004 tsunami. Asia Pacific Viewpoint, 49(2), 137-154.

Saul, J. L. J., \& Landau, J. (2004). Facilitating family and community resilience in response to major disaster. Living beyond loss: Death in the family. 2nd ed. New York: WW Norton \& Co, 293-306.

Walsh, F. (2007): Traumatic Loss and Major Disasters: Strengthening Family and Community Resilience. Family process. (46) (2). 103-108.

World Bank. (2013). Cohesive Communities Create Resilience. retrieved from: http://blogs.worldbank.org/developmenttalk/conflict/frontpage?page=56. 10/25/2017.

WV4_Results. Study \#Zimbabwe 2001_v20180912. retrieved from: http://www.worldvaluessurvey.org/WVSDocumentationWV6.jsp 01/12/2019.

WV5_Results. Study \#Thailand 2007_v20180912. retrieved from: http://www.worldvaluessurvey.org/WVSDocumentationWV5.jsp 02/05/2019.

WV6_Results. Study \#Zimbabwe 2012_v20180912. retrieved from: http://www.worldvaluessurvey.org/WVSDocumentationWV6.jsp 01/14/2019.

WV6_Results. Study \#Thailand 2013_v20180912. retrieved from: http://www.worldvaluessurvey.org/WVSDocumentationWV6.jsp 02/03/2019. 